\title{
Az egészség-egyenlőtlenségek megjelenítése a 60-as években
}

\author{
Presentations of the health inequities in the 60's
}

\author{
Szerző: Tarkó Klára $₫$ \\ Szegedi Tudományegyetem
}

Beküldve: 2019. 12. 14

doi: 10.24365/ef.v60i5.549

Kulcsszavak: egészség-egyenlőtlenség; egészségügyi kulturáltság; cigányság; falu; tanya

Keywords: health inequity; culture of health; gypsies, villages; boonies

A magyar lakosság körében tapasztalható egészségeltérések jelentős része a társadalmigazdasági egyenlőtlenségek függvénye, következménye ${ }^{1}$, melyet egészség-egyenlőtlenségeknek nevezünk. Az egészség-egyenlőtlenségek befolyásoló tényezői a lakóhely, etnikai hovatartozás, a foglalkozás, a nemek szerinti megoszlás, a vallási hovatartozás, az iskolai végzettség, a társadalmigazdasági helyzet, a munkaerőpiaci pozíció és a társadalmi tőke, társadalmi erőforrások. ${ }^{2}$ A fenti tényezők közül a 60-as években akkor még Egészségügyi Felvilágosítás néven megjelenő Egészségfejlesztés folyóirat az etnikai hovatartozást (cigányság) és a lakóhelyet (tanyasi és falusi lakosság) emelte ki, melyek kapcsán az iskolai végzettség, a műveltség (kiemelten az egészségműveltség), a munkaerőpiaci pozíció, a foglalkozás és az anyagi helyzet jelent meg elemzési szempontként.

A jelen áttekintésben vizsgált 10 év évfolyamaiban 7 cikk foglalkozott a cigány lakosságot, 3 cikk a tanyasi és falusi lakosságot érintő kérdésekkel az egészségnevelő munka során.

A következő összefoglaló a 60-as évekre vonatkozik, mindennemú egyezés a jelennel csupán a véletlen múve - vagy talán mégsem ...
A cigány lakosság egészségügyi kulturáltsága és az azzal kapcsolatos feladatok

A 60-as évek elején mintegy 200000 főre becsült cigány lakosság 33\%-a rendelkezett állandó munkával, 32\% élt alkalmi munkából és 35\% volt munkanélküli. ${ }^{3}$ Alkalmazásukat az iskolai végzettség hiánya, a nomád életmód és a többségi társadalom velük szembeni idegenkedése nehezítette. A cigány lakosság gyermekeinek többsége addig járt iskolába, amíg be nem állt az őszi esős időjárás, az iskolákban pedig kiközösítették őket öltözékük, higiénés viszonyaik és kommunikációs képességeik elmaradottsága miatt. Az ipar és a mezőgazdaság az előítéletek miatt félt alkalmazni a cigány munkavállalókat. ${ }^{4}$ A cikkek elmaradott népcsoportként aposztrofálták a cigányságot, akik kapcsán a legfőbb feladat az átnevelés, a teljes értékú állampolgárrá válás, a munkához szoktatás, az anyagi megalapozás, a letelepítés, az emberhez méltó lakhatás biztosítása, a kulturális színvonal emelése, az intenzív felvilágosító munka, a megkülönböztetés megakadályozása ${ }^{3}$, valamint az asszimiláció ${ }^{5}$ volt, mindezek lehetőség szerint társadalmi összefogásban. Székely Lajos úgy fogalmazott, hogy "a néprétegeknél évszázados hiányosságokat és megrögzött szokásrendet kell megváltoztatni" ${ }^{6}$ Hasonlóan vélekedett 
Tóth Sándor is, aki azt írta, hogy „a cigányságon csak úgy lehet segíteni, ha kiemelik őket évszázados elkülönültségükből. Meg kell szüntetni a velük kapcsolatos és túlzott előítéleteket, fel kell világosítani őket és környezetüket a való helyzetről. Helyhez és munkához kötöttséggel be kell vonni valamenynyiöket a dolgozók társadalmába és ezáltal meg kell erősíteni teljes emberi értékükben, hogy ne érezzék magukat csak megtürteknek". ${ }^{7}$

\section{A cigányság egészségügyi helyzete és egészségmagatartása}

1960. december 1. és 10. között Somogy és Borsod megye 38 községe cigány lakossága körében kérdőíves felmérés történt az egészségügyi kulturáltság mutatóinak vizsgálatára. ${ }^{6}$ A vizsgálati minta tartalmazott letelepedett, részben beolvadt; részben elkülönített cigánytelepen élő; és elkülönített telepen élő, kunyhókban, putrikban, primitív házakban lakó; valamint nomád életmódot folytató, kóborló cigány származásúakat. A lakhatás milyensége, a bútorokkal és használati cikkekkel való ellátottság egyenes arányban állt a lakók munkaerőpiaci helyzetével, vagyis a rendszeres keresők arányszáma a padlós lakásokban volt a legmagasabb. A mosdótálakkal ugyancsak ezekben a lakásokban találkoztak a kutatók, míg a putriknak csak 31\%-a rendelkezett ezekkel. Az összes lakások csupán 59\%-ban volt ágynemű, 17\%-ban feküdt egy fekhelyen csak egy személy. Magas volt az egy lakásban lakók létszáma is. A legtöbb lakás egyetlen helyiséggel rendelkezett. A padlós lakások vízvételi lehetőségét $72 \%$-ban a kút jelentette, míg a putrikban ez csak $10 \%$-ot tett ki. Az összes lakások 1/3-ához sem illemhely, sem pöcegödör nem tartozott. A szemetet 34\%-ban a trágyadombon, 23\%-ban a szemétdombon gyújtötték. A lakások 46\%-ában a tǔzhely fútött, $33 \%$-ban a kemence és csak $16 \%$ rendelkezett kályhával. A családok 74\%-a petróleumvilágítást használt. A lakások tisztasága 85\%-ban kielégítő volt. Összességében a vizsgálati minta 31\%-a érte el a környezethigiénés alapkövetelményeket. ${ }^{6}$

Étkezési szokásaikat tekintve a felnőtt és a gyermek lakosság 30\%-a csupán egyszer evett naponta főttételt. Táplálkozásukban a fő problémát az egyoldalúság okozta, 61\% élettanilag hiányosan táplálkozott. 63\%-ban a burgonya és a bab jelentette a fő táplálékot. A rendszeres tehéntej fogyasztás ritka jelenség volt.

Problémát jelentett az időszakos, rendszertelen és nagymértékű alkoholfogyasztás. Érdekes megállapítás, hogy „a munka- és életkörülmények javulásával párhuzamosan mutatkozik jelenleg az alkoholfogyasztás gyakoriságának emelkedése is". ${ }^{6}$ A 10-14 éves gyerekek 30\%-a fogyasztott alkalomszerüen alkoholt. A megvizsgált cigány lakosság 82\%-a dohányzott, a gyerekek 30\%-a volt rendszeres dohányos.

10-12\%-ot tett ki a hetenként vagy annál is ritkábban mosakodók aránya, valamint természetesnek tartották a közös tisztálkodószerek használatát. A fehérnemúváltás 84-91\%-ban heti vagy ennél ritkább gyakoriságú volt.

Az orvoshoz fordulás gyakorisága alacsony volt, $86 \%$ nem vett igénybe orvosi kezelést. A férfiak $72 \%$-a, a nők 32\%-a és a gyerekek 90\%-a még életében nem volt fogorvosnál. A gyógyító szolgálat ingyenes igénybevételének lehetősége a cigány lakosság munkaviszonyba lépésével párhuzamosan emelkedett.

A terhes tanácsadást főként a fiatalabb korosztályú anyák vették figyelembe. A megvizsgált szülő nők 63\%-a otthon szült. A többgyerekes anyák kevésbé vettek igénybe egészségügyi szaksegítséget a szüléskor. A születések arányszáma magasnak, a terhességmegszakítások száma viszont alacsonynak volt mondható. A 3 hónaposnál fiatalabb csecsemőket az anyák kivétel nélkül szoptatták. A megkérdezettek 22\%-a nem használt pelenkát.

Cserteg Sándor a marcali járás cigánysága körében végzett egészségügyi felvilágosító munka tapasztalatait mutatta be, az 1960 és 1962 decemberében végzett egészségügyi és kulturális viszonyokat feltáró vizsgálat segítségével. ${ }^{8}$ Megnevezte a cigánysággal kapcsolatos sajátos problémákat, mint az alacsony múveltségi színvonal, a lakhatásbeli rétegződés, a többségi társadalom ellenállása, a vándorlás, a tetvesség, az alacsony munkaintenzitás, az írástudatlanság, a döghús-fogyasztás. A bemutatott felvilágosító munka leghatásosabb módszerének az egyéni nevelés mutatkozott. A cigány telepek 
tisztasági mozgalomba való bevonása annyira sikeres volt, hogy egyes cigány telepek tisztábbnak bizonyultak, mint a szomszédos községek. Azt is megemlítette a cikk, hogy elkezdődött a megyében típusterv alapján a cigány családok részére történő házépítés, a cigány telepek felszámolása érdekében. Az írástudatlanság felszámolása érdekében pedig 1962-ben az összes tanköteles cigány gyermeket beiskolázták.

Tóth Sándor a Somogy megyei KÖJÁL tisztasági mozgalmát, a telepek közötti tisztasági versenyt mutatta be, mint a cigányság egészségügyi kulturáltsága emelésének eszközét. ${ }^{7}$ A megyében 145 cigány származású egészségügyi felelőst állítottak munkába, akiknek munkáját az egészségügyi dolgozók ellenőrizték és segítették. A KÖJÁL munkatársai nagy igyekezetet és győzni akarást tapasztaltak, a nyertes alsóbogátiak személyi és környezeti higiénében maximális pontszámot értek el. 1967-es írásában Tóth Sándor a cigányok között végzett egészségnevelés eredményeiről számolt be. ${ }^{5}$ Kiemelte, hogy a célzott felvilágosító munka alapja a cigányok életkörülményeinek és különleges lelkivilágának ismerete, valamint az őslakosság (a környezet) bevonása. 1965-re a cigány telepek aránya csökkent, ezáltal a cigányok emberhez méltó, egészségesebb épületekben éltek. Azok a cigányok, akik állandó munkaviszonyban éltek, elpolgárosodtak, szokásaikban és életmódjukban is megközelítették az őslakosságot. Mindezek arra engedtek következtetni, hogy a cigányság problémáinak megoldásához vezető legjobb út az asszimilálódás. E folyamatban pedig fontos szerepet töltött be az egészségkulturális nevelő munka. A változás hordozói az iskolás gyerekek lehetnek, akik a múveltség megszerzésével már nem akarnak majd a régi módon élni.

Burján József a Fejér megyei cigány telepek tisztasági mozgalmát nevezte példaértékúnek. ${ }^{4}$ Itt is cigány származású tisztasági felelősöket bíztak meg a feladattal, aki személyükben igyekeztek jó példát mutatni, ösztönözni a többieket és a vajda bizalmát is megnyerték. A cigány lakosság és az egészségügyi hatóság között közvetlen kapcsolat tudott kialakulni, mivel megközelítésüket a cigányok számára közeli és fontos kérdésekre irányították. A mozgalom eredményeként a cigány lakosság közegészségügyi körülményei megközelítették a falusi lakosságét.

Horváth Mihály a cigány csecsemők és gyermekek egészségügyi helyzetét elemezte. ${ }^{9}$ Megjegyezte, hogy magas a koraszülöttség, a 2500 gr alatti születési súly, ezért nagyon fontos volt a koraszülöttséghez vezető tényezőkről felvilágosítani a cigány anyákat. Ilyen például a korai, 13-14 éves korban kötött házasság és terhesség, amikor a női test még nem teljesen érett a terhesség kihordására. De ugyanúgy fontos a megfelelő táplálkozás vagy a kellő pihenés is. Csecsemőkorban és gyerekkorban problémát jelentett a gyakran helytelen táplálás, mely hiányos testi és szellemi fejlődést eredményezhetett.

Mindegyik ismertetett cikk közvetlenül vagy közvetve az alábbi intézkedésekben látja a cigány lakosság helyzetének javulását:

- az anyagi helyzet javulása

- egészségügyi felvilágosító és nevelő munka

- analfabétizmus felszámolása

- általános múveltség emelése

- megfelelő munkalehetőségek, állandó munkaviszony biztosítása

- engedély nélküli kóborlás megakadályozása

- letelepedés biztosítása

- lakáskörülmények javítása

- a többségi társadalom idegenkedésének felszámolása.

Tanyasi és falusi lakosság egészségügyi kulturáltsága

Zalányi az egészségügyi felvilágosítást végző körzeti orvosok munkáját mutatta be, akiknek munkáját nehezítette „az egészségügyi kulturáltság igen alacsony fokán álló, csökönyösen maradi, paraszti életszemlélet". ${ }^{10}$ Fontos volt, hogy a körzeti orvos minél több pedagógust megnyerjen segítőtársául e munka elvégzéséhez. Kiemelte az egészségügyi jó szokás kialakításának szemléletét, mint sikeres stratégiát, azaz a cselekedtető felvilágositást.

Szentkereszty az egészségügyi ismeretterjesztést nehezítő tényezőnek tekintette, hogy a dolgozó parasztság jelentős része szétszórt tanyákon élt. ${ }^{11}$ A falusi orvos szerepét nem csak a gyógyításban határozta meg, hanem tanító pedagógusként is 
kellett funkcionálnia. Az orvos egészségügyi nevelőmunkájának legfőbb segítői a védőnők, körzeti ápolónők, az orvosírnokok, az egészségőrök, a gyógyszerészek, és az állatorvosok voltak. Az egészségügyi szakszemélyzet részéről a hatékony felvilágosítás záloga az volt, hogy a lakosság felé közérthetően közvetítse az információkat, ügyeljen a szakkifejezések kerülésére. A legfontosabb érintendő területek a következők voltak: személyiés környezeti higiéné, fertőző betegségek, balesetek megelőzése, elsősegélynyújtás, tejkezelés, helyes táplálkozás, növényvédőszerek használata, családtervezés. A felvilágosításba segítőtársként még fontos volt az értelmiségi rétegek, kiemelten a pedagógusok bevonása, a tanyai iskolákon keresztül. A példamutatás és a tisztasági mozgalmak a falusi és a tanyavilágban is megjelentek. Az ismeretterjesztésben fontos szerepet szántak továbbá a megyei-könyvtárhálózatnak, az egészségre játszva nevelő könyvek biztosításának.
Hegedűs és Róna a falusi és tanyai gyerekek 5 év alatt bekövetkezett életmódváltozásáról számoltak be Csongrád-megyei mintán végzett kérdőíves felméréseik nyomán. ${ }^{12} \mathrm{~A}$ vizsgálat eredményei a következőkben összegezhetők: „A belterületi és tanyai iskolás gyermekek életmódjában jelentős az eltérés. Bár a tanyai gyermekek egy múszakban tanulnak, de hosszabb időt vesz igénybe az iskola megközelítése, több időt kell házimunkára fordítaniok. Kevesebbet tanulnak otthon, az iskolában osztatlan tanításban vesznek részt, kevesebb gyermeknek van a tanyán külön ágya ... A tanyaiak éjszakai pihenése viszont kedvezőbb képet mutat a belterületieknél. A személyi higiénés viszonyok a belterületen és tanyán nagyjából egyformák, egyik helyen sem mutatnak túl kedvező képet”. A kutatók megfogalmazták, hogy az életkörülmények javítása érdekében széles körben kell terjeszteni a gyermekek helyes életmódjára és optimális napirendjére vonatkozó ismeretanyagot.

\section{HIVATKOZÁSOK}

\footnotetext{
${ }^{1}$ Vitrai J, et al. Egészségügyi ellátáshoz való hozzáférés egyenlőtlenségei Magyarországon - Javaslatok az ellátási kapacitások elérhetőségének javításához. EgészségMonitor Kutató és Tanácsadó Nonprofit Közhasznú Kft. Budapest. 2011. pp. 95.

2 Uzzoli A: A hazai egészségi állapot alakulása és területi különbségei a válság éveiben. In: Nyári D (szerk.). Kockázat - Konfliktus - Kihívás. SZTE TTK Természeti Földrajzi és Geoinformatikai Tanszék, Szeged. 2012. pp. $931-940$.

${ }^{3}$ Bártfai Z.: A cigánylakosság egészségügyi kulturáltságának emelésével kapcsolatos feladatok. 1962:15-18.

${ }^{4}$ Burján J. Beszámoló a Fejér megyei cigánytelepek tisztasági mozgalmáról. Egészségügyi felvilágosítás. 1963:50-53.

${ }^{5}$ Tóth S. Az egészségnevelés eredményei a cigányok közt. Egészségügyi felvilágosítás. 1967; VIII:174-177.

${ }^{6}$ Székely L. A cigány lakosság egészségügyi kulturáltsága. Egészségügyi felvilágosítás. 1962;1II:26-42.

${ }^{7}$ Tóth S. Az alsóbogáti állami gazdaságban szerzett tapasztalatok a cigánylakosság egészségügyi nevelésében. Egészségügyi felvilágosítás. 1964:30-33.

${ }^{8}$ Cserteg S. A marcali járás cigánysága körében végzett egészségügyi felvilágosító munka tapasztalatai. Egészségügyi felvilágosítás. 1963;IV:17-18.

${ }^{9}$ Horváth M. Cigánycsecsemőkkel és gyermekkel kapcsolatos egészségügyi felvilágosítási munka eredményei. Egészségügyi felvilágosítás. 1964:35-39.

10 Zalányi S. Az egészségügyi kulturáltság a falusi-tanyai lakosság körében. Egészségügyi felvilágosítás. 1963;IV:15-16.

${ }^{11}$ Szentkereszty L. A tanyai egészségügyi ismeretterjesztés. Egészségügyi felvilágosítás. 1966;VII:75-79.

12 Hegedűs Gy, Róna B. Falusi és tanyai gyermekek életmódjának változása öt év alatt. Egészségügyi felvilágosítás. 1970;XI:253-258.
} 